\title{
The Effect of Globalization on Foreign Trade and Investment in Eurasian Countries
}

\author{
Prof. Dr. Ahmet Incekara (Istanbul University, Turkey) \\ Ph.D. Candidate Mesut Savrul (Çanakkale Onsekiz Mart University, Turkey)
}

\begin{abstract}
Globalization includes a comprehensive transformation in technological, economic, politic and scientific fields and it's largest impact has been on developing countries is acceleration of liberalization of foreign trade and investment. Regarding foreign trade and investment is vital for economic growth of developing countries such as Eurasian countries which are lack of capital to support their growth, the effects of globalization come into prominence. In this study how the globalization movements have affected trade and investment structure of the region is assessed. The data is collected from KOF Swiss Economic Institute, World Bank and UNCTAD. The results have shown that although trade and investment relations with the rest of the world, they are still limited within the region and stronger economic integrations are necessary to develop them.
\end{abstract}

JEL codes: F02, F13, F21

\section{Introduction}

Globalization has shown an active presence mainly in economic, political, social, cultural and technological fields. In this respect globalization has largely brought free movement of labour, capital and goods. Transportation, communications, advances in manufacturing and political developments in the last 20 years have accelerated the globalization.

Globalization is the result of great changes in political, economic, technological and social areas. Globalization revived capital flows, trade, investment and movement of labour force between countries (Toprak, 2001:8-9). Foreign trade and direct investment helps developing countries to confront the international competition by boosting their economy, increasing productivity and export capacity. Foreign direct investments reflect positively to one-time balance sheet of the host country (Candemir, 2007).

Eurasia geography is one of the ascending economic powers of the world due to its great economic potential. Eurasia region is usually define as the states turned up with the collapse of Soviet Union but because of its geopolitical situation many other neighbour countries such as Turkey, Iran, Russia, India and China and even some unions such as EU are closely linked with the region. The regions economy is based on natural resources and trade is limited. The capital is short in many of the countries in the region but labour is abundant.

The capital flows that the region needs to support its economic growth is attached to foreign trade and investments which is closely related with globalization. In this respect globalization of Eurasian countries has a strategic importance for both the countries of the region and world economy.

\section{Globalization, Foreign Trade and Investment}

After industrial revolution an incredible increase in production, technological developments, and increase of speed of transportation, ease in communication helped capital, labour, information and technology movement to get intense between countries besides goods and services. As a result national economies connected to each other with movements which are gradually getting more complex and dense (Ekodiyalog, 2012) which laid the first foundations of globalization.

Globalization term was first used by McLuhan and Fiore (1968) when they introduced the concept of the "global village". Globalization is characterized by the growth of the international trade of goods and services, the growth in foreign direct investment as well as the political and social linkages that accompany growing economic integration (Gaston and Khalid, 2010: 3).

Globalization includes a comprehensive transformation in technological, economic, politic and scientific fields since 1990's. This process integrated the countries in economy just as the other many fields. As a natural result of the integration liquidity of knowledge, labour, capital and goods fairly increased. This liquidity brought new construction processes together. Parallel to globalization, Macroeconomic balances have been reasonably affected due to dynamic movements of foreign capital, in this framework globalization affected economy deeply as well as culture and politics.

\subsection{The Effects of Globalization on Economy}

In globalization cycle, multi-national companies and economic integrations have been effective in the world economy by creating competition between countries. In this context, the developing countries which are losing their competitive advantages open their economies to global markets through economic integrations and multinational companies (İncekara and Savrul, 2011: 7). 
Globalization is the tendency of investment funds and businesses to move beyond domestic and national markets to other markets around the globe, allowing them to become interconnected with different markets. Proponents of globalization say that it helps developing nations "catch up" to industrialized nations much faster, through increased employment and technological advances, and Asian economies are often highlighted as examples of this process (Investopedia, 2012).

According to Lucas; what expected from globalization is to increase the effectiveness of resource allocation and economic growth by obtaining the maximum yield from all kinds of factors thanks to the fluidity of the international factors (Yay, 2009: 3). The goal of globalization is to provide organizations a superior competitive position with lower operating costs, to gain greater numbers of products, services and consumers. This approach to competition is gained via diversification of resources, the creation and development of new investment opportunities by opening up additional markets, and accessing new raw materials and resources((Investopedia, 2012).

Financial and industrial globalization is increasing substantially and is creating new opportunities for both industrialized and developing countries. However industrialized and developing countries basically have different expectations in this process. While integration and globalization of the developing countries mean of initiating industrialization, it means increase of the rate of industrialization for the developed countries (İncekara, 1995: 87). The largest impact has been on developing countries, who now are able to attract foreign investors and foreign capital. This has led to both positive and negative effects for those countries (Mohr, 2012).

- Increased Standard of Living: Economic globalization gives governments of developing nations access to foreign lending. When these funds are used on infrastructure including roads, health care, education, and social services, the standard of living in the country increases. If the money is used only selectively, however, not all citizens will participate in the benefits.

- Access to New Markets: Globalization leads to freer trade between countries. This is one of its largest benefits to developing nations. Homegrown industries see trade barriers fall and have access to a much wider international market. The growth this generates allows companies to develop new technologies and produce new products and services.

- Widening Disparity in Incomes: While an influx of foreign companies and foreign capital creates a reduction in overall unemployment and poverty, it can also increase the wage gap between those who are educated and those who are not. Over the longer term, education levels will rise as the financial health of developing countries rise, but in the short term, some of the poor will become poorer. Not everyone will participate in an elevation of living standards.

- Decreased Employment: The influx of foreign companies into developing countries increases employment in many sectors, especially for skilled workers. However, improvements in technology come with the new businesses and that technology spreads to domestic companies. Automation in the manufacturing and agricultural sectors lessens the need for unskilled labor and unemployment rises in those sectors. If there is no infrastructure to help the unemployed train for the globalized economy, social services in the country may become strained trying to care for the new underclass.

However the World Bank reports that without sound domestic financial systems, globalization of economy can lead to disastrous effects in developing countries. Less wealthy countries from those among the industrialized nations may not have the same highly-accentuated beneficial effect from globalization as more wealthy countries, measured by GDP per capita etc. Although free trade increases opportunities for international trade, it also increases the risk of failure for smaller companies that cannot compete globally. Additionally, free trade may drive up production and labor costs, including higher wages for more skilled workforce. Domestic industries in some countries may be endangered due to comparative or absolute advantage of other countries in specific industries. Another possible danger and harmful effect is the overuse and abuse of natural resources to meet new higher demands in the production of goods.

Globalization is characterized by the growth of the international trade of goods and services, the growth in foreign direct investment as well as the political and social linkages that accompany growing economic integration. Outwardly, the driving forces seem to be the decline in administrative barriers to trade, sharp falls in the costs of transportation and communication, fragmentation of production processes and the development in information and communication technology (Gaston and Khalid, 2010: 3).

Economic globalization enabled the cross country free flow of information, ideas, technologies, goods, services, capital, finance and people. This cross border integration had different dimensions - cultural, social, political and economic. More or less the economic integration happened through four channels (Hrmbusiness, 2012);

- Trade in goods and services

- Movement of capital

- Flow of finance

- Movement of people 
In this respect the effects of globalization on foreign trade and investment come forward.

\subsection{Globalization of Foreign Trade}

From the theoretical aspect, international trade ensures allocating different resources and that has to be consistent. This specialization in the processes leads to better productivity. Restrictive trade barriers in emerging economies only impede growth and emerging economies can reap the benefits of international trade if only all the resources are utilized in full potential. This is where the importance of reducing the tariff and non-tariff barriers crop up (Mapsofindia, 2012). Promotion of liberal trading activities is perhaps the greatest contribution of globalization, acting as a favour to the world economy. The advantages enjoyed by countries engaged in mutual free trades can be summarized as follows (EconomyWatch, 2010):

- Considerable reduction in the cost of transportation, especially with the development of containerization with respect to overseas ocean shipments,

- Decrease or abolition of control over capital and the capital market,

- Formation of free zones for carrying out commercial activities, against payment of little or no tariffs at all,

- Decrease, abolition or synchronization of subsidies in domestic trades,

- Decrease or abolition of every kind of tariffs.

To give an example to the contribution of globalization to the specific nature of today's international, the world's gross domestic product elevated 6 times while world merchandise exports were elevating 20 times in the period after World War II. Besides commercial goods, a similar increase in exports of manufactured goods and services were experienced. main reasons for this increase in world trade during period were reductions in trade taxes, tariffs and restrictions (Bayar, 2008:27-28).

The share of trade in GDP for all developing countries increased from 34.6 percent in 1990 to 51.6 percent in 20008. This is considerably above both the level of trade, and its growth, in the developed countries during the same period. The increasing importance of trade for developing countries affected low and middle income countries in similar ways, although the share of trade in low income countries remained below that for middle income countries: the former increased from 26.7 percent to 41.3 percent and the latter from 36.6 to 53.5 . It is worth noting that even for the least developed countries as a whole, the share of trade in GDP exceeds that of the developed countries (Penalver, 2002: 4-5).

\subsection{Globalization of Foreign Investment}

Today, unlike the traditional nation-state structure, production activities are accomplished in a global context and different stages of production are settled in different regions. In this process multinational companies emerge as the most important unit which contribute movements of foreign direct investments, portfolio investments and international trade (Bayar, 2008: 27-28). The production base of a developing economy gets enhanced due to capital flows across countries. The mobility of capital only enabled savings for the entire globe and exhibited high investment potential. A country's economic growth doesn't, however, get barred by domestic savings. Foreign capital inflow does play an important role in the development of an economy (Mapsofindia, 2012).

The rising importance of foreign investment is a good indication of the rising importance of multinational corporations for the global economy and for developing countries. multinational corporations almost exclusively have their origin in developed countries, and along with increasing globalization, these typically very large private corporations have emerged as the most important private economic actors that developing countries are confronted with in their dealings with the global economy (Pedersen, 2008: 15).

Foreign investment going to developing countries has also increased substantially during the 1990s but, contrary to trade, it remains at levels well below those of industrialized countries. From a sector perspective, foreign investment has been substantial, at different times and different regions, in manufacturing, oil extraction and mineral mining, trade as well as public utilities. Such different transactions are generated by different country conditions and opportunities, and have different impacts on the host country. Thus a detailed look at the components of foreign investment flows will be required when focusing on specific regions and countries. At this point, however, we will look at the overall trends, noting also some of the global structural changes within foreign investment (Penalver, 2002: 4-5).

Globalization is seen too often as an pervasive force in the modern world. Yet, even now, there is still considerable dispute over what the term might mean, let alone what it might portend (Amin and Thrift, 1995: 12). Although positive and negative effects of foreign direct investment on the local economy are heavily debated its contribution on accumulation of capital is obvious. Because the investment is not directed equally to every country, growth and development environment of the developing countries are interrogated. It's emphasized that macroeconomic stability, policy consistency, improved governance environment, sound infrastructure, fullfunctioning financial system and input-output convenience in production process are necessary to attract foreign direct investment (Kar and Tatlisöz, 2008: 441). 


\section{Globalization and Eurasian Economies}

Eurasia region has a geographical area of approximately 23 million $\mathrm{m}^{2}$, an average growth rate of $5.75 \%$ and a GNP of 1.2 trillion USD (Bahar, 2008:20). When China and India added to this GNP it counts more than half of total world GNP. Development rates of developping countries of Eurasia have a larger potential to overcome global crisis compared to industrialized countries. China and India is expected to go on developing for 20-30 more years and join economic powers of the world and some of today's facts will radically change (Apak, 2009:8). When the GNP of the region and foresights regarded the place of the region for the world economy is much more important.

After the Cold War, globalization which made its mark on new order started big races between countries. Today regional alliances which are established by the countries which have common benefits to resist negative effects of this fact is still important (Ekodiyalog, 2009). Eurasia which is regarded as the heart of the world became a region where all the global and regional powers tried to become effective because of its strategic position and rich energy resources. Latterly accelerating race of establishing military bases and providing rent from the area totally changed the dimension of the rivalry in the region (Bayar, 2008: 79-81). This process accelerated social, politic and economic transformation of the region. The course can be seen in Figure 1.

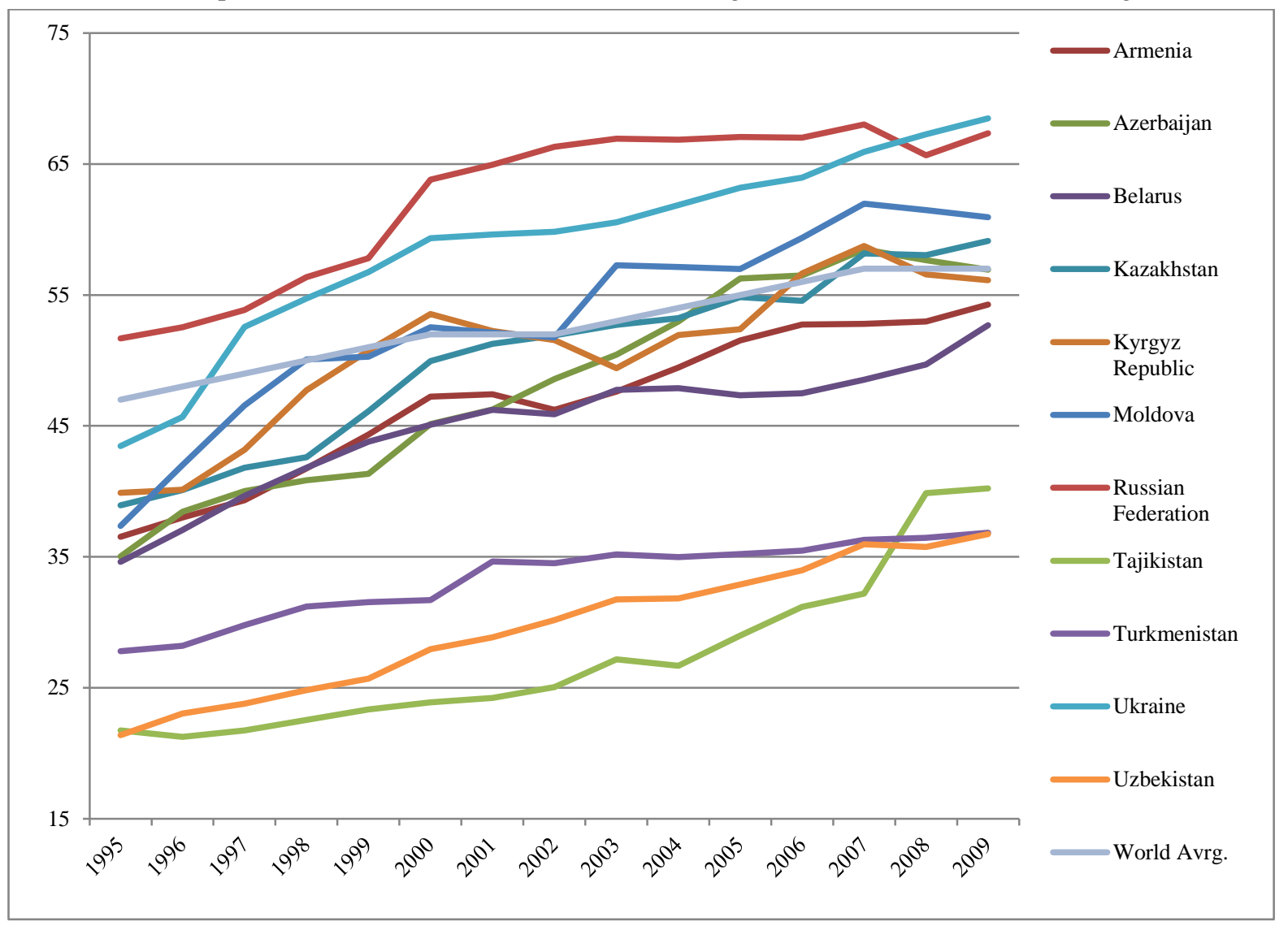

Figure 1. Index of Globalization 1995-2009 Source: KOF Swiss Economic Institute, 2012 KOF Index of Globalization, 2012, Zurich.

When the KOF Index of Globalization which measures the economic, social and political dimensions of globalization has been evaluated, within 1995-2009 period globalization index values of Eurasian Countries has grown ranging from $30 \%$ to $85 \%$ and $54 \%$ on the average, the growth rate has been $21 \%$ for the world. In this respect it can be concluded that the countries of the region is globalizing much faster than the rest of the world.

Deichmann (2003: 1767-78) mentioned that since human power and social capital is the most important determinant of the distribution of investment, foreign direct investment is still going on to flow into the transition economies of Eurasia. Another condition necessary for the inflow of foreign capital is raw resources most of which is mass in the region. The foreign investment flows towards and outside the region is shown in Figure 2 and 3.

The figures show that although it is too limited compared to the developed and transition economies, inward foreign direct investment flows developed much faster than outward ones. The underlying reason for the direction of the flow is that although the region has mass raw materials, it is lack of capital. The investment flows accelerated by 2000s in particular but the global crisis has badly affected the flows. 
Export and import volume of Eurasia area is too low when it is compared with the average world rates. Trade volume of the area is approximately 40 billon USD. The reason for this is more than half of export goods of most of the countries in the region such as Russia, Iran, Azerbaijan, Tajikistan, Turkmenistan, Kazakhstan and Mongolia are natural resources and they import industrial good with the revenue they gathered from export of natural resources (Uzunoğlu, 2009: 11) so their trade structure isn't self sufficient. Import and export volume of Eurasina countries are summarized in figure 4 and 5.

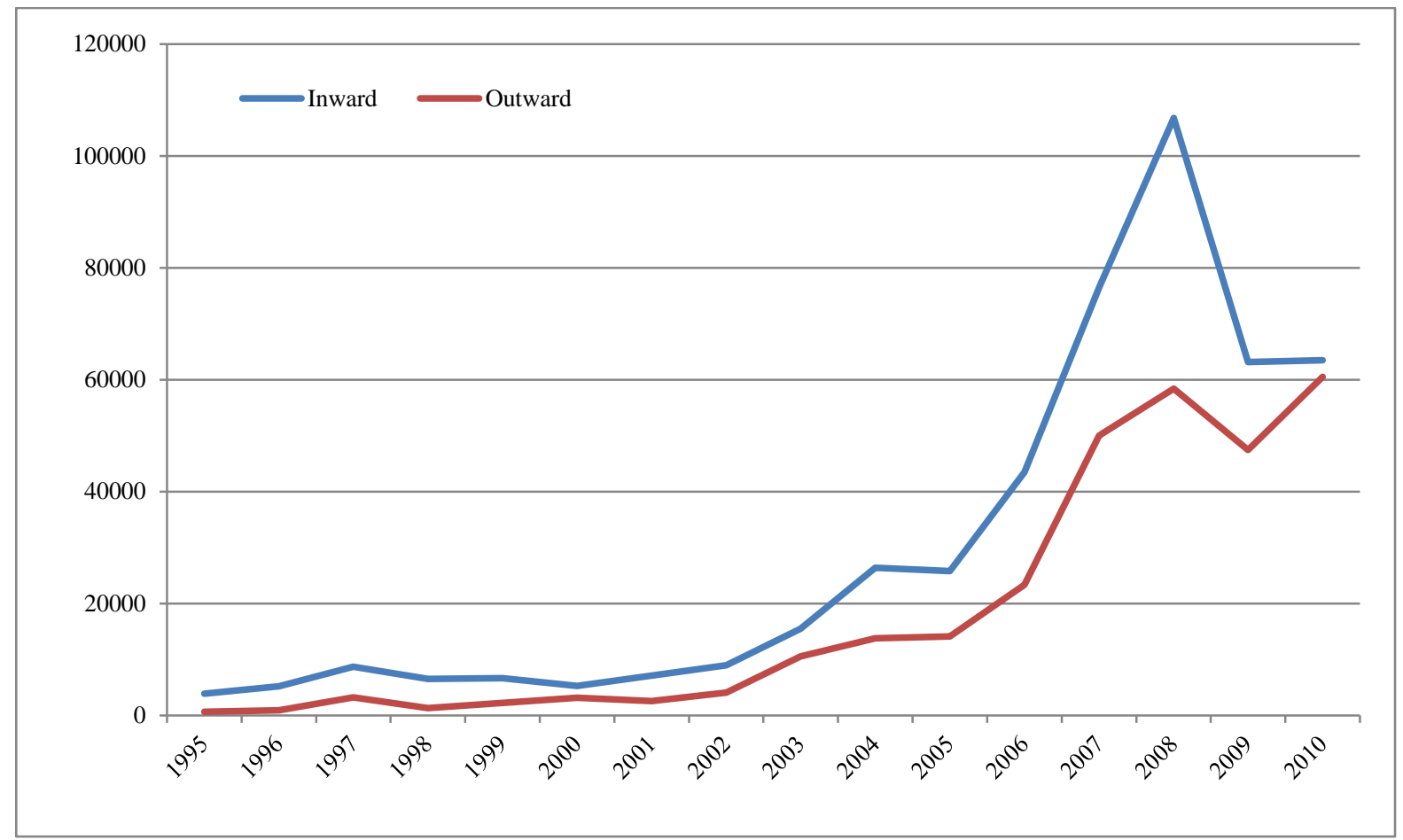

Figure 2. Inward and Outward Foreign Direct Investment Flows in Eurasian Economies, Annual, 1995-2010 US Dollars at Current Prices and Current Exchange Rates in Millions Source: Unctad, Unctadstat, Inward and outward foreign direct investment flows, 2012

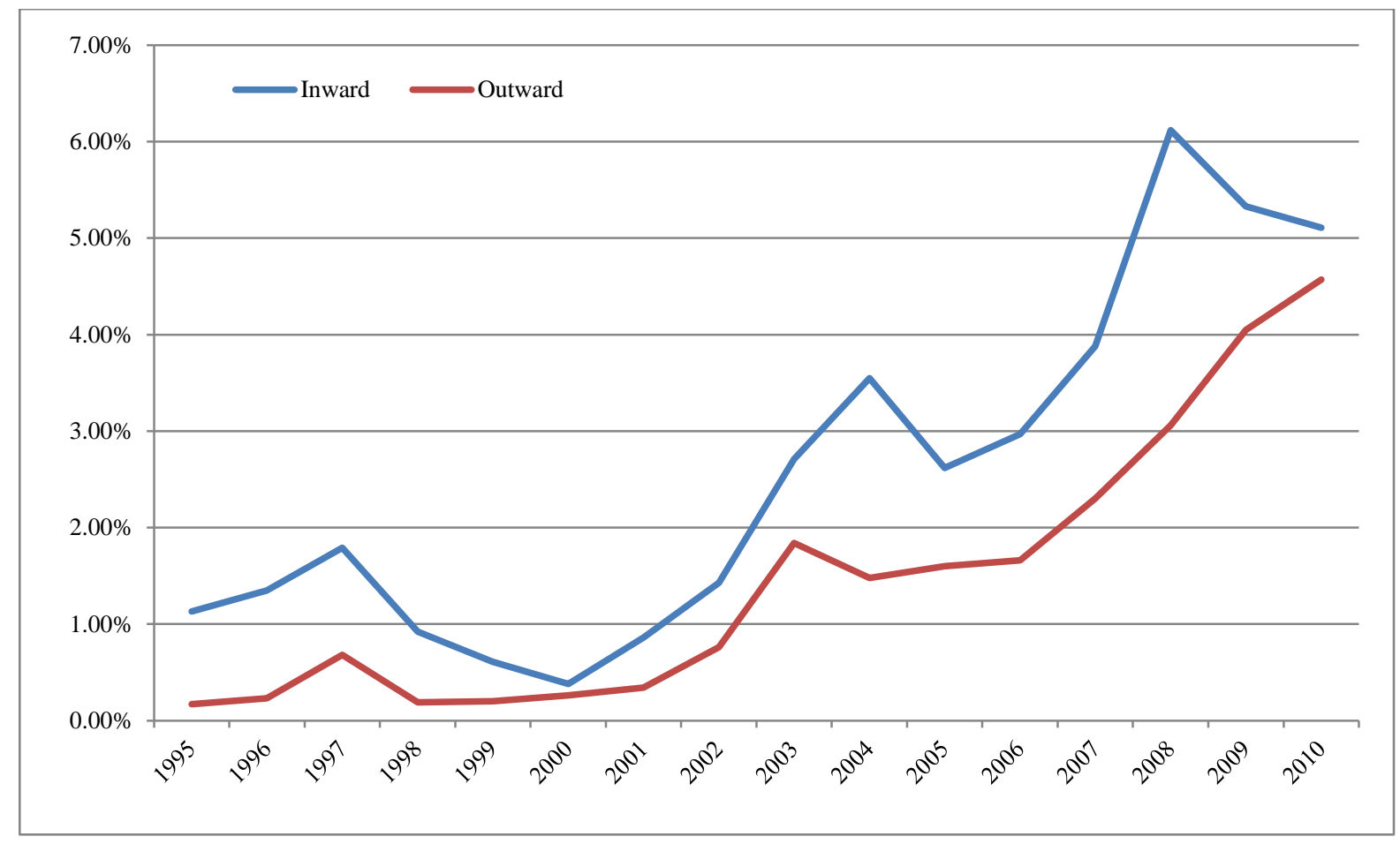

Figure 3. Inward and Outward Foreign Direct Investment Flows in Eurasian Economies, Annual, 1995-2010 Percentage Of Total World. Source: Unctad, Unctadstat, Inward and outward foreign direct investment flows, 2012 


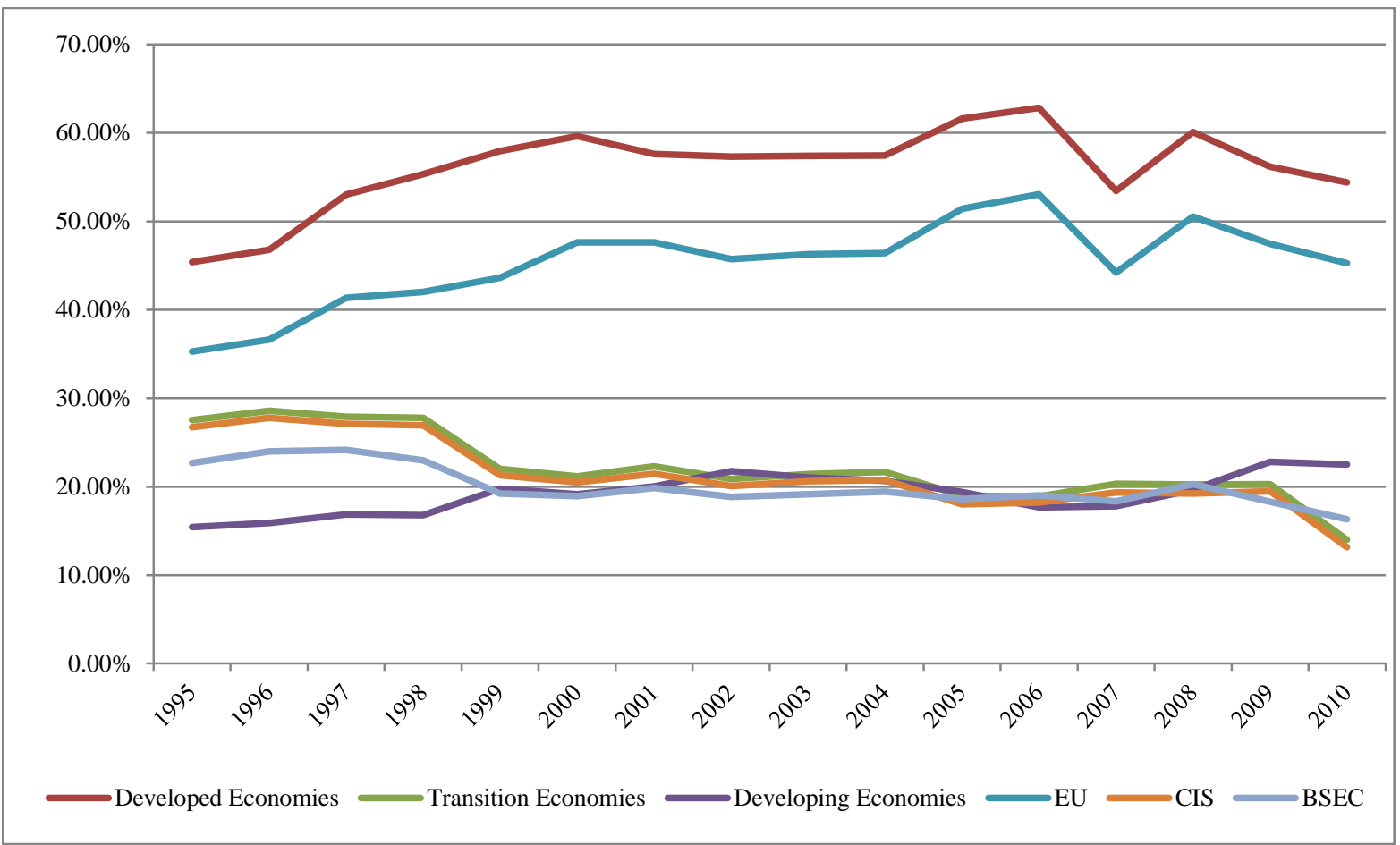

Figure 4. Export Volume of Eurasian Countries by Trade partners (Million \$) Source: Unctad, Unctadstat, Merchandise Trade Balance, 2012

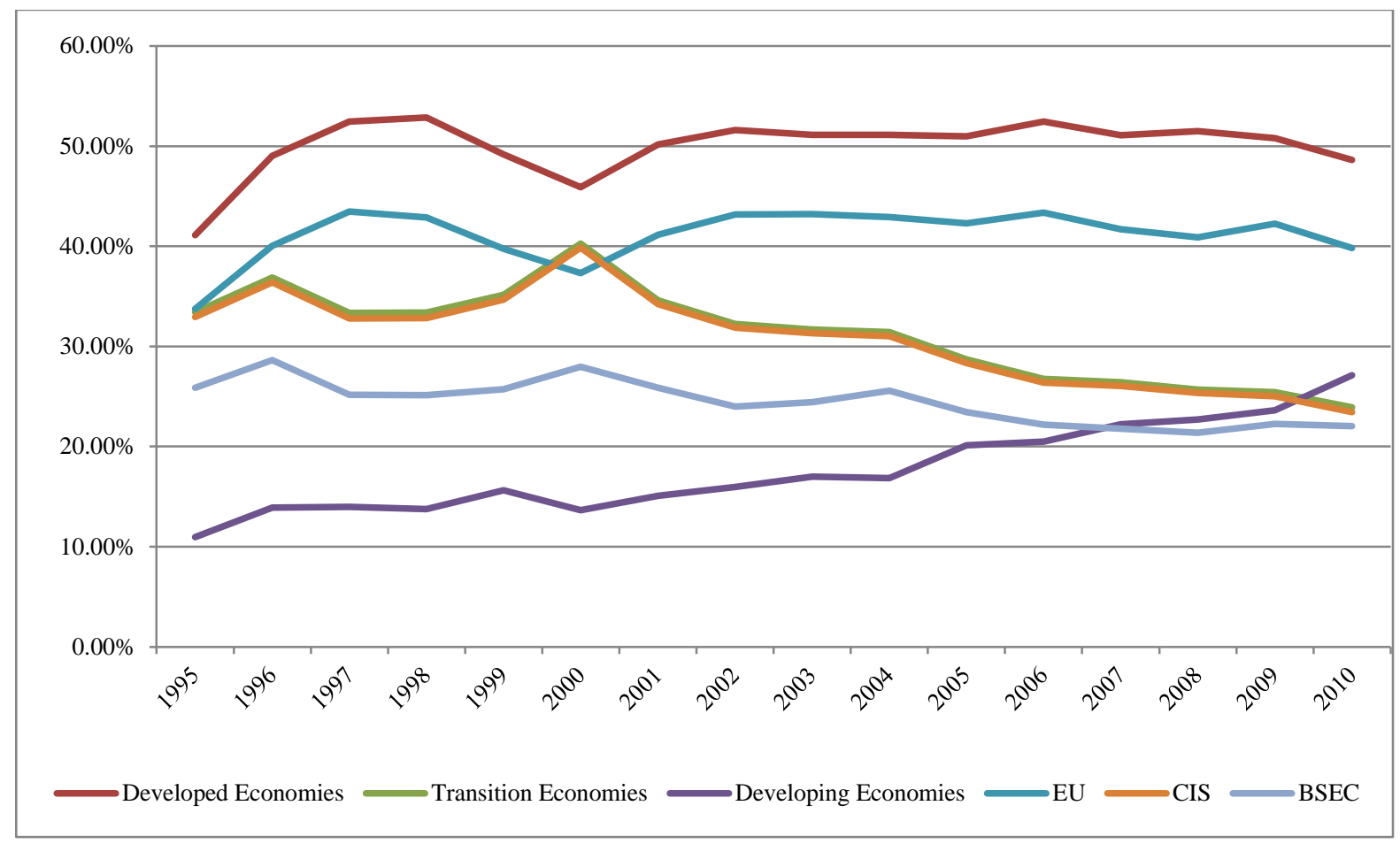

Figure 5. Import Volume of Eurasian Countries by Trade partners (Million \$) Source: Unctad, Unctadstat, Merchandise Trade Balance, 2012

The changes in export and import volume of Eurasian countries between 1995-2010 show that trade share of developed countries including EU increased aproximately 10\%. On the other hand trade share of CIS and BSEC countries, majority of which are Eurasian countries, is in a declining trend. Exports towards CIS countries declined $103 \%$ and $38 \%$ towards BSEC countries in the last 15 yeards. Similarly CIS countries lost $40 \%$ of their import volume while the figure is $\% 17$ for the BSEC. 


\section{Conclusion and Suggestions}

Developing countries are in need of foreign capital to improve their infrastructure, to finance their foreign debts and ensure economic growth. Depending on the reasons, these countries offer incentives such as removing barriers to trade, liberalizing their financial system, reducing tax and increasing interest rates. And indeed investors head towards these countries because of the better opportunities they can provide. These facilities greatly contributed foreign investments to shift to developing and less developed regions after 1990s.

Eurasia geography is one of the ascending economic powers of the world due to its great economic potential. The regions economy is based on natural resources and trade is limited. The capital is short in many of the countries in the region but labour is abundant. Globalization has possitive effects on removing barriers of foreign trade and attract foreigd direct investment. Due to it's strategic importance many developed economies closely deal with the region which helps Eurasian countries to globalize much faster than the rest of the world in the last 15 years.

Another way for developing countries to enlarge their market and attract foreign investment is economic integrations. Many countries in the region head towards associations to develop their economic relations and to have a voice in global markets. Altough the countries of the region are members of integrations such as CIS and BSEC, their investments within the region is limited and the trade share within the region is declining which is substituted by developed countries.

Despite the fact that this process helps globalization of the region, it prevents colloboration within the region, efficient use of factors in the region, removal of regional disparities and the region to emerge as an economic power. In this framework either existing economic integrations should be made more functional or more stronger integrations should be founded in the region.

\section{References}

- Amin A., Thrift N. (1995), "Globalization, Institutions, and Regional Development in Europe", European Science Foundation Series, Oxford University Press, UK.

- Angie M., (2012), Demand Media, "The Effects of Economic Globalization on Developing Countries", http://smallbusiness.chron.com/effects-economic-globalization-developing-countries-3906. html (22.05.2012)

- $\quad$ Apak, S. (2009), "Enerji Pazarında Avrasya Ülkelerinin Küresel Etkinliğin Artırılmasında Finansal Piyasaların Önemi", http://sadiuzunoglu.trakya.edu.tr/doc/finans.pdf (30.04.2012).

- Bayar F. (2008), "Küreselleşme Kavramı ve Küreselleşme Sürecinde Türkiye", Uluslararası Ekonomik Sorunlar, Say1: 32.

- Candemir, A. (2007), "Doğrudan Yabancı Sermaye Yatırımlarının Ekonomık Büyüme ve İstihdam Üzerindeki Etkileri", İşveren, TİSK, May, http://www.tisk.org.tr/isverensayfa.asp?yazi_id= 1721\&id =87 (17.05.2012).

- Deichmann, J. (2003), "Foreign Direct Investment in the Eurasian Transition States", Eastern European Economics, Vol. 41, Number 1 / January- February 2003, pp.5-34.

- Dige Pedersen Jorgen, (2008), "Globalization, Development and the State", Palgrave Macmillan, UK.

- Ekodiyalog, (2009), Avrasya Ekonomisi, http://www.ekodialog.com/Makaleler/ avrasya_ekonomisi.html (17.05.2012).

- Ekodiyalog, (2012), Uluslararası Ekonomik İlişkiler, http://www.ekodialog.com/uluslarara siekonomi/ uluslararasi_ekonomik_iliskiler.html (24.05.2012).

- Economy Watch, (2010), "Effects of Globalization", http://www.econom ywatch.com/ economicstheory/globalization/effects.html (02.06.2012).

- Gaston, Noel and Ahmed M. Khalid, (2010), "Globalization and Economic Integration" Edward Elgar Publishing Limited, UK.

- $\quad$ "Hrmbusiness, Implications and Effects of Globalization On Our Economy and our Workforce", (2008), http://www.hrmbusiness.com/2008/08/implications-and-effects-of.html (11.05.2012).

- İncekara, Ahmet; Savrul, Mesut. (2011), “İktisat Fakültesi Mecmuası”, Küreselleşme, Büyüme ve Ekonomik Entegrasyonlar: Türkiye Açısından Bir Değerlendirme, Cilt: 61, Sayı:2, 3-22.

- İ́ncekara, Ahmet. (1995), "Globalleşme ve Bölgeselleşme Sürecinde NAFTA ve Etkileri", İTO Yayınları, İstanbul.

- Investopedia, (2012), "Globalization: Progress Or Profiteering?", http://www.investopedia. com/articles/07/globalization.asp\#ixzz1xiEePRTT (02.06.2012). 
- Investopedia, (2012), "How Globalization Affects Developed Countries", http://www.invest opedia.com/ art icles/economics/10/globalization-developed-countries.asp\#ixzz1xiEMgqx3 (22.05.2012).

- Kar Muhsin, Tatlısöz, Fatma, (2008), "Türkiye'de Doğrudan Yabanci Sermaye Hareketlerini Belirleyen Faktörlerin Ekonometrik Analizi", KMU IIIBF Dergisi, Year.10, No.14, December.

- KOF Swiss Economic Institute, (2012), "KOF Index of Globalization", Zurich.

- Mapsofindia, (2012), "Impact of Globalization", June 14, 2012, http://business. mapsofindia.com/ global ization/impact.html (22.05.2012).

- Penalver Manuel, (2002), "Globalization, FDI and Growth: A Regional and Country Perspective, Capacity Development Workshop on the State, the Private Sector and Civil Society: Partnerships for Development and Democracy", "United Nations Department of Economic and Social Affairs Marrakesh", Morocco, 10-13 December, 2002.

- Şanlı Bahar (2008); "Ekonomik Entegrasyon Teorsi Çerçevesinde Avrasya Birliği’nin Olabilirliği", Atatürk Üniversitesi İktisadi ve İdari Bilimler Fakültesi Dergisi,_Vol:22, No:1, p.19-26.

- $\quad$ Toprak, Metin, (2001), "Küreselleşen Dünyada Türkiye Ekonomisi Serbest Piyasa Devriminin Serüveni", Siyasal Kitabevi, Ankara.

- $\quad$ Turan Yay, (2009), Ekonomi Bilimleri Dergisi, Cilt 1, Sayı 1.

- Tutor2u, "Globalisation-Effects", http://tutor2u.net/economics/revision-notes/a2-macro-global isationeffects. html, tutor $2 \mathrm{u}$.

- Unctad, Unctadstat (2012), "Inward and Outward Foreign Direct İnvestment Flows".

- Unctad, Unctadstat (2012), "Merchandise Trade Balance".

- Uzunoğlu Sadi vd., (2009), "Avrasya Bölgesine Yönelik Gelişme Stratejileri ve Potansiyel Sektör Araştırması", http://canerekizceleroglu.trakya.edu.tr/kaynaklar/8.pdf s.11-14.

- Uzunoğlu, Sadi, Atakişi, Ahmet ve Yürük, Mehmet Serkan (2006); "Avrasya Bölgesinde Ekonomik Entegrasyonun Uygulanabilirliği Üzerine Bir İnceleme", Küreselleşme Bağlamında Avrasya Toplumları Konferansı, Uluslararası Atatürk Alatoo Üniversitesi, p.1-20. http://serkanyuruk. trakya.edu.tr/yayin/ entegrasyon.pdf (03.05.2012). 